\title{
Teacher Training: Music Methods for an Internationalized Approach to Instruction
}

\author{
Sharri VanAlstine \\ Correspondence: Sharri VanAlstine, University of Wisconsin-Whitewater, USA
}

Received: September 9, 2015 Accepted: September 24, $2015 \quad$ Online Published: October 9, 2015

doi:10.11114/jets.v4i1.1074

URL: http://dx.doi.org/10.11114/jets.v4i1.1074

\begin{abstract}
How can music teachers and students connect with music and cultures in an honest and meaningful manner? Can music instruction increase intercultural skills and international-mindedness? If these initiatives are important, pre-service teachers need to know how to address these issues in their classroom content and pedagogy. In an effort to assist pre-service elementary classroom teachers to integrate music into their classrooms using an internationalized approach to instruction, I created eight strategies for their lesson planning and pedagogy. The pre-service teachers developed and taught lessons utilizing these strategies in music content integrated with any of the other required content areas. Putting these strategies into use in their lesson planning and teaching affected their preparation and teaching. According to the pre-service teachers, these strategies, embedded in their planning and teaching became the most difficult and meaningful learning associated with their pre-service music methods training. This article will address why internationalizing music content is important, the strategies to do so, as well as an example created by pre-service elementary school teachers.
\end{abstract}

Keywords: classroom teachers, integration, international, music education, pre-service, teacher training

\section{Leading to an Internationalized Approach to Instruction}

\subsection{Cultural Disquiet}

What happens when you come to the end of your second day in a new school, and realize your 15 years of successful music teaching has not adequately prepared you for your new student population? Of course, students and groups in any school are different every year, but teaching in a new setting rapidly highlighted some large gaps in my education and experience. My new position included both high school and middle school choral music and music appreciation in an international boarding school in southwestern Germany. Although a portion of the students were from Germany, France, and Switzerland, the majority of the student population was comprised of expatriates from Australia, Canada, England, South Korea, and the United States. Most of these students, however, were more familiar with their international school dorm culture and the country/culture where their parents worked in Eastern and Western Europe, Asia, and Africa than with the musical and instructional norms from my experience teaching in the United States. Feeling the kind of panic I had not felt in years of teaching, I began floundering through all of the literature I could find related to "third-culture kids" and international education.

\subsection{The Dilemma}

Although the materials on international education were helpful, none specifically addressed music education content or the long-term ramifications for appropriate (or inappropriate) music curriculum and methods. There were outstanding resources related to International Baccalaureate (IB) schools and curriculum (Hill, 2000, 2001, 2007; International Baccalaureate Organization, 2004, 2005-2011; Walker, 2000, 2002), how to internationalize the college campus and curriculum (DiYanni, 2007; Green, 2002, 2007), and the merits of international education (Duckworth, Walker-Levy, \& Levy, 2005; Hayden, Thompson, \& Walker, 2002; International Baccalaureate Organization," 2005-2011), but none that provided me with practical insight into how to plan and teach music "internationally" on a daily basis.

Upon returning to the United States, I continued to seriously study international music education and teacher training. At the same time, I began teaching the music methods requirement for elementary classroom teachers at a large university in the north-central region of the United States. Although the university had a strong international education background and initiative ("Office of International Programs," 2009), I discovered none of the pre-service teachers were familiar with international education, nor were they preparing to incorporate internationalized instruction into their 
future curriculum or classrooms. My journey had really begun as a new teacher in an international school, but I could see the need for all children to learn to become more internationally-minded, regardless of their background or location. The concept of an internationalized approach to instruction developed, therefore, as I worked with these pre-service teachers - in an effort to help them become more internationally-minded. Mindful that these pre-service teachers would become the next generation of educators, I wanted to create a process by which they could create instruction that would assist the children in their classrooms to also become more internationally-minded.

\section{Theoretical Framework for an International Approach to Instruction (IAI)}

Part of my struggle with internationalizing content in the classroom was related to how to define and operationalize outcomes. Therefore, after a great deal of reading and action research with my pre-service teachers, my theoretical framework for internationalizing instruction developed. Authors, educators, and psychologists who affected the development of my theoretical framework include: Howard Gardner, Ian Hill, Joan Wink, Abraham Maslow, Terry Haywood, Sue Snyder, Dee Hansen, Elaine Bernstorf, Gayle M. Stuber, and Charles Hoffer.

In addition to reading literature related to child-centered learning, international-mindedness, perspectives, and integrated learning, I designed discussions and assignments for my pre-service teachers to learn about their own perspectives of these issues. Classroom discussions around international-mindedness revealed a wide range of understanding and bias, and these perspectives were reflected in the lesson plans the pre-service teachers created. Integrated lessons they designed demonstrated the need for instruction in the creation of truly integrated lessons, not lessons that simply included a song or some musical movement. Lesson procedures the pre-service teachers included in their lesson plans were often heavily slanted toward teacher-directed learning or "telling" rather than learner-centered activities and instruction. Perhaps the most revealing was the listening lesson I created to assess their ability to hear and analyze music from a variety of perspectives. Culturally bound, we are all likely to hear music through our own cultural and experiential background unless someone suggests we do otherwise. As I noted the areas the pre-service teachers in their relative youth and professional inexperience demonstrated, my theoretical framework emerged to meet the needs in their education.

There are, therefore, four over-arching components in my theoretical framework of an internationalized approach to instruction (IAI), including education that: 1) is learner-centered (Gardner, 1993, 1999; Hill, 2007; Maslow, 1954; Wink 2004), 2) creates international-mindedness (Haywood, 2007), 3) creates appreciation for a multiplicity of perspectives (Hill, 2007), and 4) is integrated and interdisciplinary in nature (Hoffer, 2005; Hansen, Bernstorf, \& Stuber, 2007; Snyder, 2001). See Figure 1 for a more detailed illustration of the theoretical framework. These components all coincide and support the tenets of an IAI in music education.

As I began teaching through this framework, asking pre-service teachers to do likewise, I began to notice growth in their ability to craft instruction that was learner-centered, that addressed multiple perspectives, and instruction that was integrated and/or interdisciplinary. Their greatest struggle was with international-mindedness, so I developed the combination of the eight strategies of an internationalized approach to instruction (IAI) to further guide them in their lesson construction toward international-mindedness. My hope is that intentionally addressing the individual needs of students and empowering them to make musical decisions within the context of integrated, contextualized music instruction will help in the development of internationally-minded music-making and analysis.

According to Piper, Dryden-Peterson, and Kim (2006), internationalized instruction is designed to effect change in the disparity of educational access, equity, and quality. This will not happen if students are not challenged to understand, respect, and have active compassion for people and cultures. Internationalizing curriculum, therefore, should do more than inform content; "it requires the development of a sense of moral responsibility among students directed not only towards their families and nations, but also towards humanity as a whole" (Rizvi, 2007a, p. 400). For that reason, an IAI, should be action-oriented (Crossley, 1999; Watson, 1999). The state of education on a global scale is confronted as students are challenged to look beyond "today" and their own cultural biases to the more global implications of their musicianship, skill development, and experiences. Understanding and appreciation through integrated/interdisciplinary music instruction will encourage students to be engaged in the social changes required to address hegemonic structures that entrap as well as meet the music educational needs of children (Countryman, 2009; Freire, 2000; Wink, 2004). 


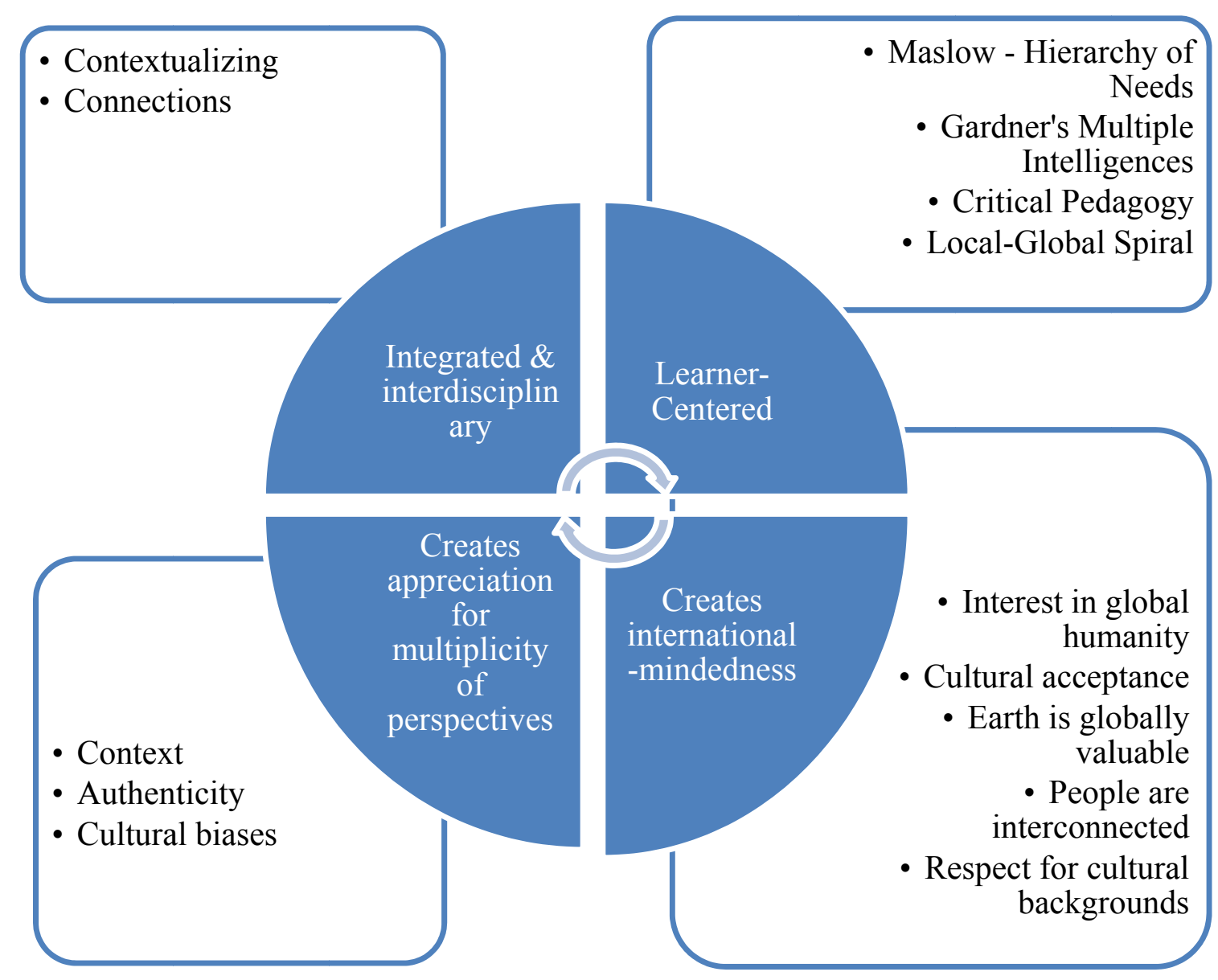

Figure 1. Theoretical Framework (VanAlstine, 2011)

\section{What is an Internationalized Approach to Instruction (IAI)?}

The IAI is simply designed as a tactical guide for creating and structuring instruction. Utilizing the IAI strategies, the goal is to move teachers and students towards the outcomes of the theoretical framework of an IAI - instruction that 1) is learner-centered, 2) creates international-mindedness, 3) creates appreciation for a multiplicity of perspectives, and 4) is integrated and interdisciplinary in nature. Having settled upon my framework, I needed to figure out (for myself as well as for my students who were training to be teachers) how to arrive at the objectives outlined in my framework. The strategies have provided the practical "how-to" of the framework. They have guided me in lesson construction and pedagogy as well as in the expectations and assignments for the pre-service teachers with whom I work.

Bearing in mind my theoretical framework and Haywood's construction of international-mindedness (2007), I formulated the following eight strategies to challenge my pre-service teachers' development, and to provide them with some concrete "steps" towards internationalizing the lessons they were creating and teaching. The culminating project of their music methods class was designed to help them to attain an IAI through lesson construction, content choices, methods, and rehearsal and performance practices by adhering as closely as possible to the eight strategies of an IAI (See Table 1).

Table 1. Strategies to Internationalize Instruction

\begin{tabular}{l}
\hline International Pedagogical Strategies \\
\hline 1. Local to global spiral \\
2. Contextualize all content \\
3. Go in-depth into one culture before addressing another \\
4. Present multiple perspectives of content \\
5. Use authentic materials and practices \\
6. Learn about connections and similarities, not only differences \\
7. Address multiple learning styles \\
8. Integrate across content areas
\end{tabular}

Strategy 1: Local to Global/Global to Local Spiral (I haven't changed this, but is there supposed to be a space here?) 
In the first week of high school choir in the international school where I taught, I discovered several of my new students classified the first pitch of an F-major scale as either "f," "do," or "fa" dependent upon their culturally-ingrained prior knowledge. Of course, they were all correct contingent upon the musical systems from which they were coming. In class, therefore, we looked into why each answer was correct and spent time during the course of the school year using each musical system in the context of the choral repertoire. By exploring each system, the students were able to connect what they knew within their musical culture as well as what they did not know in a different and equally viable system. Connecting instruction to students in one's classroom is a logical and effective catalyst for musical and cultural exploration (Campbell 2004). Furthermore, this provides opportunity for local connections, authentic and community interaction, and the contextualization of musical traditions housed within the classroom and community. Although the "fixed do" practices of Serbia were unfamiliar to some students, they explored this system, learning several Serbian songs and dances from a Serbian student (a culture-bearer) in the choir. Through experiences like this, students can gain, a greater understanding and appreciation for the peoples and musical traditions within their own community or classroom, and perhaps even beyond the borders of their region. For instance, according to Nethsinghe (2009) engaging local culture-bearers near Melbourne, Australia - an area rich in Sri Lankan immigrants and musicians - brought Sri Lankan music and culture to the children and community. Looking within one's community may not only determine a culture and music to study, it may also yield experts and expertise in musical and cultural instruction.

On the other hand, internationalized instruction may not necessarily be linked with the students or community. Factors that may influence music curriculum and methods choices may include: current events, a sister school association, personal ties and relationships, or a passion for a style of music. For instance, following the tsunami in Japan in 2011, students in my choir began discussing what they could do to provide some relief. After a variety of suggestions, one young soprano suggested a benefit concert, including the musical traditions of the Japanese people. As they explored more ideas, they investigated various genres of Japanese vocal and choral music, performance practices, and connections with the other arts. A great deal of research, care, and a significant growth in understanding and appreciation for Japan, its dilemma, and its heritage grew out of this catastrophic event. Although the students were not initially connected to Japan through the community or their prior experience, this tangibly connected them to people and music in a concrete and meaningful manner. This is an equally valid approach to music content and methods and enables students to learn music-making associated with cultures or people outside the borders of their own community. In this manner, music-making practices from a global location impacts the local classroom and community, and so on.

\section{Strategy 2: Addressing Multiple Learning Styles/Multiple Intelligences}

When content is contextualized and integrated, it is more likely to connect with the strengths of students in at least one content area, learning style, or intelligence (Elliott, 2005; Gardner, 1999). This enables students to grow musically in the mode in which they are most inclined (visually, aurally, kinesthetically, tactile, etc.) as well as to stretch them in their relative musical and intellectual weaknesses. For example, according to Poole (2004) in his study of bhangra musical practices (from northern India) in England, the music is learned largely utilizing an oral/aural approach. If music instruction is crafted in an authentic manner, therefore, bhangra music is taught orally/aurally, and becomes the deciding factor in the pedagogy of musical instruction.

Similarly, investing in the musical learning style and performance practices of a traditionally aural culture, like Japan (Malm, 1972), could be a musical feast for a student whose learning style is largely aural. In the case of my choir, we sought to learn two Japanese folk songs through oral/aural means, rather than using musical scores. This meant we listened to recordings. During rehearsals I sang one part at a time, repeating each part as necessary while student singers echoed to the best of their ability.

It was quite interesting to note that some students learned far more quickly than they had on previous songs with a choral score in hand. I saw enthusiasm and smiles on the faces of these students as they turned to help some of their peers who were struggling to learn in this manner. Ironically, the best music-readers in the class were amongst the slowest to learn and expressed the most frustration with this approach. As a teacher, I appreciated their frustration because I am a fervent note-reader myself. However, this gave them (and me) an opportunity to enhance their aural-learning skills. Furthermore, those students who are aural-learners flourished in this method in a way I had not previously experienced with choral singing largely approached through note-reading. In this manner, the skills of both types of learners were strengthened and enhanced. Furthermore, their own musicianship and understanding of Japanese forms of music developed as they experienced a new approach to learning choral music than we had explored previously, expanding their own music-making and musical ways of knowing.

\section{Strategy 3: Contextualize Content}

All music instruction is structured within the context of the culture from which it derives, both stylistically and pedagogically (Addo, 1997; Custodero, 2007; Hargreaves \& North, 2001; Rizvi, 2007a; Snowball, 2007a). Careful 
study of music within its cultural/historical/generational/functional context lends greater insight into performance practices and musicianship (Addo, 2009). Furthermore, this affords students the opportunity to experience, understand, and make connections with music, people, and cultures (Agawu, 2003; Hargreaves \& North, 2001; Nzewi, 2003). The music, therefore, is perceived valuable from its inherent value as well as its association with a people or culture (Addo, 2008, 2009; Agawu, 2003; McCarthy, 2004; Rizvi, 2007b; Snowball, 2007b). According to Green's (2002) study of music education in England, teachers noted the importance of contextualization, both in terms of meaning and content as well as in performance practices with the help of primary sources. Teachers (Green, 2002) indicated their musical instruction was connected to providing context for the students' musical and intercultural development.

For instance, relative to the study of Japanese music in my former choir, students researched the composers, the style of music, and the rehearsal and performance techniques commonly used in the songs we selected. As they discovered how our songs were performed and what the poetry actually meant in context, the students grew in their understanding of Japanese music and culture. Insights from the Japanese family who helped us solidified and modified what students had discovered in their research. They were able to give cultural clues we could not discern from reading, providing us with greater and very meaningful contextual information. The depth of the students' research, including the assistance of our Japanese friends, also helped students to discover connections with the music, people, and culture.

\section{Strategy 4: In-Depth Study of One Culture at a Time}

The focused study of one musical culture for a period of time before learning about another is critical to internationalizing content (Addo, 2009; Hansen, 2002). It provides students with the opportunity to develop their musicianship specific to the styles and practices of the culture, including folk, classical, and popular musical styles. Often, as musicianship develops, so too does one's appreciation for a musical style or piece. Focused study for a length of time will allow for more comprehensive musical understanding and expertise. It will also foster greater depth for understanding for how the music functions, similarities and differences, and its context, all of which create connections, musical meaning, and greater appreciation for music, musicianship, people, and culture. As noted earlier, our study of Japanese music and culture was truly singular in focus. It was specific to a traumatic world and Japanese event in its conception, but it gave students a real focus for their research, study, and discovery. The repertoire I had originally selected and rehearsed was set aside as we focused solely on our Japanese literature and study. Focusing completely on our Japanese literature allowed us the time we needed to learn about the Japanese culture, music, and performance practices in a way that would have been impossible had we continued to work on our previously selected songs.

\section{Strategy 5: Multiple Perspectives}

The inclusion of a variety of perspectives within the curriculum and pedagogy (Hicks, 2003; Skelton, 2002) requires "bi- or multi-lateral cultural perspectives within education programs" (Addo, 2009, p. 1). An IAI, therefore, encourages students to understand and appreciate music and its context through a variety of lenses, including those related to geography, gender, ethnicity, history, and culture (Addo, 2009; Raby \& Valeau, 2007). Consequently, students' exposure to a diversity of perspectives gives them first-hand experience with intercultural development and a plethora of musical styles and music-making opportunities. Furthermore, seeing music and its origin through a variety of lenses enables students to grasp the breadth of context and culture omitted within the context of instruction from one perspective, regardless of its authenticity.

In this instance, the students' primary lens was their own western background and worldview. As they continued to rehearse and prepare for the performance, however, they connected with a Japanese American family that gave the choir some insight into their culture (Japanese American, not solely Japanese), and specifically, the effect of the tsunami on their extended family living in Japan. This made the choir students' experience more meaningful, gaining a better grasp of the fear and uncertainty of the situation facing the Japanese people following the tsunami. It also made them quite passionate about honoring the music and performance practices they had learned despite the challenges this presented to some of the singers in the choir. This was the very reason the visual learners were willing to struggle with the oral/aural process of learning these songs. They did not want to just learn the songs; they wanted to learn them in the same manner a Japanese student might learn them. I was thrilled because it expanded our musicianship, created a connection we would not have otherwise experienced, and gave us a new perspective on music.

\section{Strategy 6: Include Similarities/Connections as well as Differences}

A fundamental objective of an IAI is the development of respect and compassion for people with whom students may have no initial connection as they study and create music. This requires the study and search for similarities as well as differences included in the music, its lyrics, its function, its context, and its performance practices (Agawu, 2003; Hicks, 2003; Skelton, 2002). As a reflection of culture, music and musical practices give students the opportunity to grow in their knowledge of people and culture even as their musicianship grows. Inherent in this process is not only the discovery of those musical and cultural characteristics that are the same or different, but a growing awareness of the 
value of both, "respecting and protecting differences among multi-country diversities (Raby, 1999)."

In the instance of my choir, the students' initial responses related primarily to the differences between the music they had learned in choir before and the Japanese music we were learning. The most notable difference was the manner in which we learned the music - through oral/aural means. Melodic and harmonic shape and conception was also new to the students' ears and minds. As we continued, however, students began noting elements of our learning process, the music, or the poetry for which they connected. For instance, one girl noted that her church choir often learned music in the same manner - largely listening to the director and accompanist sing/play their parts. Sometimes they only had the lyrics of the songs they learned in church, and she loved learning the Japanese songs in a similar manner. Indeed, she was one of our most proficient learners, often helping the girls on either side of her learn their part. In this instance the connection she made with the manner in which Japanese music is taught thrilled her, met her learning style, and connected with her own musical background. It also enabled her to be helpful to her classmates in their learning processes.

\section{Strategy 7: Pursuing Authentic Materials and Performance Practices}

Local culture-bearers and accurate/authentic renderings of music provide the greatest insight into the music, the musicianship required to produce it, and the culture and people who originally created it. Thinking and ways of learning are culturally specific and significant (Addo, 1997; Blacking, 1987; Elliott, 1984; O'Flynn, 2005). Providing students with access to authentic music-making can broaden their musicianship and comprehension, connecting them with a variety of cultures, learning styles, and ways of knowing music (Elliott, 2005).

This aspect can be difficult if one has no concrete ties to an authentic culture-bearer who is also able to speak to musicianship. In this instance, the Japanese American family was not musically active; however, their assistance with our interpretation was useful. In addition, their personal connection and experience with the culture and land of Japan made our understanding and respect for the people and culture a personal experience, meaningful in the context of relationship as well as compassion.

\section{Strategy 8: Integrated Instruction}

Careful contextualization necessitates an integrated teaching style, effectively connecting content areas and appealing to a variety of learning styles, intelligences, and content preferences (Veblen \& Elliott, 2000). The integration involved in our Japanese music lessons included research techniques, literature analysis, and a great deal of cultural research regarding both the music and the culture as a whole. Ideally, this would have been a project that could have combined instruction in the social studies, literature, and English departments. As it was an unexpected turn of events, however, the choir students embarked on this adventure solely within the context of their choir class. Although there was certainly integrated content, an interdisciplinary approach would have better facilitated this project, utilizing the strengths and expertise of several departments on campus rather than the initiative of just one. For instance, the social studies department could have enhanced student understanding of the political and social context and ramifications associated with the nuclear power plant, the infrastructure of Japan, and how these intersected to affect people after the tsunami hit. These types of insights were beyond my expertise, but it would have served to inform our approach to, and understanding of, the music we were studying from the Japanese culture.

An IAI should also infuse the school, not only its content and methods - integrating internationalized strategies into the daily interactions throughout the school day (Gellar, 1993, 2002; Hayden \& Thompson, 1995; Skelton, 2002). This means that more than one teacher in a school working together to make learning integrated and interdisciplinary will make it more effective. Instruction that spirals from the local community to a global context can assist students to know each other better, as neighbors sharing the same community.

For instance, the Japanese friends who assisted the choir were a part of our local community. Two of their children were enrolled in our school, and their relationships with the students in the choir certainly developed during this time. I noted them "hanging out" together in the common areas even though many of them had not known each other prior to this interaction. A school-wide engagement in local, primary, and authentic sources and resources also builds more connections with the community and amongst the students who walk the hallways. Students and teachers know and understand each other better and differently, impacting not only what happens in the classroom and curriculum, but also what happens in the hallways, the playground, etc. It becomes, thereby, a worldview rather than simply a teaching framework or approach.

\section{IAI Strategies in Summary}

The strategies of an IAI are very comprehensive and may be difficult to work together in every area of content included in class all the time. For instance, finding an indigenous musical culture-bearer for every culture one wishes to include in the classroom may not be feasible, but it does not preclude the inclusion of cultural study in music and across the 
curriculum. Individually, each of the strategies is valuable, and each is commonly considered standard practice. For example, an interdisciplinary approach in which each connected content area is integrated strengthens and broadens learning opportunities (Klein). As an isolated approach, interdisciplinary instruction can meet the needs of a variety of students. Combined with the other strategies of an IAI (local to global, multiple perspectives, etc.), however, students are afforded opportunities to know music in a variety of ways that may or may not be included in an interdisciplinary approach. The interdisciplinary nature of an IAI is one of the eight strands that are combined to create music instruction crafted to develop a greater understanding and appreciation for the people and culture from which it comes, enhancing the development of international-mindedness.

\section{An Internationalized Lesson Plan}

In the elementary methods class, after implementing and developing the strategies for an IAI, I required the pre-service teachers to create integrated, internationalized units for elementary students. The following is an outline of the five lessons (See Table 2) produced by one group of these pre-service teachers. They were required to create an integrated unit using an IAI, teach a music listening lesson from the unit, and reflect on their learning subsequent to their microteaching and class discussion. The group planned a brief survey of the world's oceans before targeting the Philippines in the Pacific. While preparing they discovered that the vast diversity of Filipino islands and cultures meant that their unit lacked focus; therefore, they selected the island of Luzon, where the capitol city of Manila is located. The unit was designed to provide fourth grade students an in-depth study of Tagalog people, a large ethnic population on Luzon.

Table 2. Outline for Integrated/Internationalized Unit

\begin{tabular}{|c|c|c|c|c|}
\hline \multicolumn{5}{|c|}{$\begin{array}{c}\text { Pacific Ocean: Tagalog People } \\
\text { Grade } 4 \\
\text { Kristin, Annie, Julie, Matthew }\end{array}$} \\
\hline $\begin{array}{l}\text { Social Studies } \\
\text { Survey of the oceans } \\
\text { Survey of peoples who live } \\
\text { in Philippines } \\
\text { Government structure } \\
\text { Introduce Tagalog people } \\
\text { Music: Recordings of } \\
\text { Tagalog music with } \\
\text { descriptions of context and } \\
\text { function and musical } \\
\text { concepts }\end{array}$ & $\begin{array}{l}\text { Science } \\
\text { Climate of Luzon } \\
\text { Affect climate has on } \\
\text { Tagalog people } \\
\text { Music: Focus on form } \\
\text { and timbre to create } \\
\text { weather patterns typical } \\
\text { to climate } \\
\text { Indigenous } \\
\text { instruments: how sound } \\
\text { is created }\end{array}$ & $\begin{array}{l}\text { Language Arts } \\
\text { Tagalog poetry } \\
\text { and literature } \\
\text { Connect to } \\
\text { American poetry } \\
\text { and literature } \\
\text { Music: Re-tell } \\
\text { Tagalog poetry } \\
\text { and literature in } \\
\text { sound stories }\end{array}$ & $\begin{array}{l}\text { Math } \\
\text { Rainfall: Prediction, } \\
\text { ratio, and percentages } \\
\text { Daily, weekly, monthly, } \\
\text { annual amounts } \\
\text { Connect to food supply } \\
\text { Music: Create sounds } \\
\text { (melody) using varying } \\
\text { amounts of water in } \\
\text { bottles relative to ratio }\end{array}$ & $\begin{array}{l}\text { Music } \\
\text { Singing/Movement } \\
\text { Tagalog song } \\
\text { Method: rote, orally } \\
\text { Movement } \\
\text { Discuss/demonstrate } \\
\text { music elements } \\
\text { Musical function and } \\
\text { performance practices }\end{array}$ \\
\hline
\end{tabular}

\section{Lesson Plan Explanation with IAI Strategies Referenced}

The context for the music listening lesson was prepared by a social studies lesson introducing the region and the people. The pre-service teachers used recordings of Tagalog people creating music (authenticity) and discussed the music relative to the function and meaning of the text (in-depth study, contextualization).

The music lesson utilized Tagalog poetry and literature they were reading and analyzing in language arts, learning the poems and stories as well as speculating what this would mean to the Tagalog people (multiple perspectives, contextualization). Retelling stories and poems as sound stories, acting and creating sounds pertaining to the animals, characters, and action (multiple learning styles), and relating stories to folk tales common in old American culture (connections) were central to the lesson process.

The climate of Luzon and how that effected Tagalog culture (contextualization, in-depth study) was the focus of the science lesson. Relating this lesson to musical form, fourth-grade students were expected to create weather patterns pertinent to Luzon on homemade instruments, created to be similar to indigenous instruments of Tagalog people.

The math lesson focused on rainfall and its impact on food production. Although the musical connection was tenuous, the lesson reinforced the concept of ratios (contextualization, in-depth study). Varying amounts of water (in glasses) related to the ratio of rainfall for a day, a week, and a month. Melodies were created when the glasses were struck. This exploratory learning experience related specifically to rainfall on Luzon, but it was not connected to the Tagalog people in a meaningful, musical way.

Finally, the music lesson used a recording of a song sung by Tagalog people (authenticity). They discussed the meaning and function of the music as well as how it sounded relative to the musical elements (contextualization, in-depth study). The lesson included time to learn a 30-second portion of the song orally, without use of the piano (authenticity, multiple learning styles, and multiple perspectives). They also planned to invite local Filipino musicians into the classroom for future lessons addressing context, function, and performance practices specific to the music students would study and 
perform.

Their unit was integrated, successfully connecting content areas. The only strategy I did not detect was a meaningful connection of the local-to-global. Aside from plans to invite culture-bearers into the classroom for greater authenticity and expertise, there was no plan for how to connect instruction to the local or to the global. Upon reflection, this group noted their satisfaction with their lessons; however, they also indicated they would need more time and depth for students to really understand the complexity of the Tagalog music and culture. They were concerned that the music had inherent value and meaning and that it would be appropriately contextualized within the framework of the larger culture and community. Finally, they offered suggestions for possible future connections with a school in Manila, addressing ways their students could interact and develop relationships.

\section{Conclusion}

After struggling with how to create curriculum and methods that would develop international-mindedness and internationalized musicianship in my middle and high school students in an international school, I was surprised to note similar needs from the pre-service teachers in their music methods course at the university level. This indicates the need for the development of international-mindedness and intercultural skills within the context of music and music education. Furthermore, international competence is not dependent upon age or type of educational institution. I would suggest all students need these understandings and skills in the music studio or classroom - beginning with early childhood instruction, throughout the elementary and secondary school years, and into collegiate programming. The strategies, therefore, can be used to guide instruction throughout general and music education in an effort to move all of its participants towards greater international-mindedness. Implementing these strategies with my choir that worked on Japanese music absolutely changed the choir - musically, relationally, and in their eagerness to be part of knowing and caring for others in our community and beyond.

Therefore, particularly critical is the inclusion of an IAI in the teacher-training programs shaping the next generation of educators. The strategies of an IAI, consequently, could be tried and tested by teacher educators, implemented into methods coursework, and utilized by pre-service teachers in music and any other content area. Pre-service teachers in the music methods course indicated an IAI was one of the most important elements of the class, and critical to their future teaching (VanAlstine, 2011). Internationalizing coursework for pre-service teachers will shape the international-mindedness of future generations. Providing pre-service teachers with strategies to internationalize their content and pedagogy has the potential to impact student musicianship in new and broader exploration, as well as impact their desire and ability to live and work with peoples and cultures around the world.

\section{References}

Addo, A. O. (1997). Children's idiomatic expressions of cultural knowledge. International Journal of Music Education, os-30, 15-30. http://dx.doi.org/10.1177/025576149703000103

Addo, A. O. (2008). Toward Internationalizing General Music Teacher Education. Paper presented at the Music in School and Teacher Education (MISTE) Commission International Music Education Seminar.

Addo, A. O. (2009). Toward internationalizing general music teacher education in a US context. Journal of Research in International Education, 8(3), 1-21. http://dx.doi.org/10.1177/1475240909345816

Agawu, K. (2003). Representing African Music. New York: Routledge. http://dx.doi.org/10.4324/9781315810942

Blacking, J. (1987). Coda: Making sense of the musical world. In A. L. White (Ed.), Lost in music: Culture, style and the musical event. London and New York: Routledge \& Kegan Paul. http://dx.doi.org/10.1111/j.1467-954x.1986.tb03321.x

Countryman, J. (2009). Stumbling towards clarity: Practical issues in teaching global musics. In E. Gould, J. Countryman, C. Morton \& L. S. Rose (Eds.), Exploring Social Justice: How Music Education Might Matter (pp. 23-37). Toronto: Canadian Music Educators Association. http://dx.doi.org/10.1017/s0265051711000295

Crossley, M. (1999). Reconceptualising comparative and international education. Compare, 29(3), 249-267. http://dx.doi.org/10.1080/0305792990290305

Custodero, L. A. (2007). Harmonizing research, practice, and policy in early childhood music: A chorus of international voices (part 1). Arts Education Policy Review, 109(2), 3-5. http://dx.doi.org/10.3200/aepr.109.2.3-6

DiYanni, R. (2007). Internationalizing the US secondary and university curriculum. In M. Hayden, J. Levy \& J. Thompson (Eds.), The Sage Handbook of Research in International Education (pp. 152-163). Thousand Oaks, CA: Sage Publications. http://dx.doi.org/10.4135/9781848607866.n14

Duckworth, R. L., Walker-Levy, L., \& Levy, J. (2005). Present and future teachers of the world's children: How 
internationally-minded are they? Journal of Research in International Education, 4(3), 279-311. http://dx.doi.org/10.1177/1475240905057808

Elliott, D. J. (1984). The role of music and musical experience in modern society: Toward a global philosophy of music education. International Journal of Music Education, os-4(3), 3-8. http://dx.doi.org/10.1177/025576148400400101

Elliott, D. J. (2005). Introduction. In D. J. Elliott (Ed.), Praxial music education: Reflections and dialogues (pp. 3-18). New York: Oxford University Press. http://dx.doi.org/10.2307/3400182

Freire, P. (2000). Pedagogy of the oppressed: 30th anniversary edition. New York: Continuum.

Gardner, H. (1993). In a nutshell. In Multiple intelligences: The theory in practice (pp. 5-12). New York: BasicBooks, A Division of HarperCollins Publishers, Inc.

Gardner, H. (1999). Intelligence Reframed: Multiple Intelligences for the 21st Century. New York: Basic Books.

Gellar, C. (1993). How international are we? International Schools Journal, 1(26), 5-7.

Gellar, C. (2002). International education: A commitment to universal values. In M. Hayden, J. Thompson \& G. Walker (Eds.), International Education in Practice: Dimensions for National and International Schools (pp. 30-35). Sterling, VA: Stylus Publishing Inc.

Green, L. (2002). From the western classics to the world: Secondary music teachers' changing attitudes in england, 1982 and 1998. British Journal of Music Education, 19(1), 5-30. http://dx.doi.org/10.1017/s0265051702000116

Green, M. F. (2002). Joining the world: The challenge of internationalizing undergraduate education. Change, 34(3), 13-21. http://dx.doi.org/10.1080/00091380209601850

Green, M. F. (2007). Internationalizing community colleges: Barriers and strategies. In M. Hayden, J. Levy \& J. Thompson (Eds.), The Sage Handbook of Research in International Education (pp. 15-24). Thousand Oaks, California: Sage Publications. http://dx.doi.org/10.1002/cc.277

Hansen, D., Bernstorf, E., \& Stuber, G. M. (2007). The music and literacy connection. Lanham, Maryland: Rowman and Littlefield Education.

Hansen, H. M. (2002). Defining International Education. New Directions for Higher Education, 117, 5-12. http://dx.doi.org/10.1002/he.41

Hargreaves, D. J., \& North, A. C. (2001). Conclusions: The international perspective. In D. J. Hargreaves \& A. C. North (Eds.), Musical Development and Learning: The International Perspective (pp. 220-234). New York: Continuum.

Hayden, M., \& Thompson, J. (1995). Perceptions of international education: A preliminary study. International Review of Education, 41(5), 389-404. http://dx.doi.org/10.1007/bf01103036

Hayden, M., Thompson, J., \& Walker, G. (Eds.). (2002). International Education in Practice: Dimensions for National and International Schools. Sterling, VA: Stylus Publishing Company. http://dx.doi.org/10.5860/choice.40-4130

Haywood, T. (2007). A simple typology of international-mindedness and its implications for education. In M. Hayden, J. Levy \& J. Thompson (Eds.), The Sage Handbook of Research in International Education (pp. 79-89). Thousand Oaks, CA: Sage Publications. http://dx.doi.org/10.4135/9781848607866.n8

Hicks, D. (2003). Thirty years of global education: A reminder of key principles and precedents. Educational Review, 55(3), 265-275. http://dx.doi.org/10.1080/0013191032000118929

Hill, I. (2000). Internationally minded schools. International Schools Journal, 20(1), 24-37.

Hill, I. (2001). Curriculum development and ethics in international education. Education for Disarmament, 3, 49-58.

Hill, I. (2007). International education as developed by the International Baccalaureate Organization. In M. Hayden, J. Levy \& J. Thompson (Eds.), The Sage Handbook of Research in International Education (pp. 25-37). Thousand Oaks, CA: Sage Publications Inc. http://dx.doi.org/10.4135/9781848607866.n3

Hoffer, C. (2005). Music for elementary classroom teachers. Long Grove, IL: Waveland Press, Inc.

International Baccalaureate Organization. (2005-2011). http://www.ibo.org/

Klein, J. T. (2009). A platform for a shared discourse of interdisciplinary education. Journal of Social Science Education, $1-7$.

Malm, W. P. (1972). Personal approaches to the study of Japanese art music. Asian Music, 3(1), 35-39. http://dx.doi.org/10.2307/834103

Maslow, A. H. (1954). A theory of human motivation. In Motivation and personality (pp. 80-106). New York; Harper 
and Brothers Publishers.

McCarthy, M. (2004). Democracy, Diversity, Dialogue: Recurring Themes on the Journey Toward a Global Community. In Toward a global community: International society for music education 1953-2003, 205-212.

Nethsinghe, R. (2009). To the land of the tea trees from the island of tea: A learning experience in performing arts for children of Sri Lankan community in Melbourne. Victorian Journal of Music Education, 1, 19-28.

Nzewi, M. (2003). Acquiring knowledge of the musical arts in traditional society. In A. Herbst, M. Nzewi \& K. Agawu (Eds.), Musical Arts in Africa. Unisa, Pretoria: Unisa Press, University of South Africa.

O'Flynn, J. (2005). Re-appraising ideas of musicality in intercultural contexts of music education. International Journal of Music Education, 23(3), 191-203. http://dx.doi.org/10.1177/0255761405058238

Office of International Programs. (2009, 1/7/2010). University of Minnesota. http://www.international.umn.edu/about/

Piper, Dryden-Peterson, S., \& Kim, Y.-S. (2006). Introduction. In B. Piper, S. Dryden-Peterson \& Y.-S. Kim (Eds.), International education for the millennium: Toward access, equity, and quality (pp. 1-8). Cambridge, MA: Harvard Educational Review.

Poole, A. (2004). South Asian music education in Essex: An ethnography of bhangra. British Journal of Music Education, 21(1), 7-24. http://dx.doi.org/10.1017/s0265051703005552

Raby, R. L. (1999). Looking to the future: Report on international and global education in California community colleges. Sacramento, CA: Chancellor's Office of the California Community Colleges.

Raby, R. L., \& Valeau, E. J. (2007). Community college international education: Looking back to forecast the future. New Directions for Community Colleges, 138(Summer), 5-14. http://dx.doi.org/10.1002/cc.276

Rizvi, F. (2007). Internationalization of Curriculum: A Critical Perspective. In M. Hayden, J. Levy \& J. Thompson (Eds.), The Sage Handbook of Research in International Education (pp. 390-403). London: Sage Publications. http://dx.doi.org/10.4135/9781848607866.n33

Skelton, M. (2002). Defining 'international' in an international curriculum. In M. Hayden, J. Thompson \& G. Walker (Eds.), International Education in Practice: Dimensions for National and International Schools (pp. 39-54). Sterling, VA: Stylus Publishing Inc.

Snowball, L. (2007). Becoming more internationally-minded: International teacher certification and professional development. In M. Hayden, J. Levy \& J. Thompson (Eds.), The Sage Handbook of Research in International Education (pp. 247-255). Thousand Oaks, California: Sage Publications. http://dx.doi.org/10.4135/9781848607866.n22

Snyder, S. (2001). Connection, correlation, and integration: Developing an integrated curriculum involves more than simply creating a set of related materials, activities, and strategies. Music educators journal, 87(5), 32-39 70.

Strategic Plan of the International Baccalaureate Organization (IBO). (2004). International Baccalaureate Organization.

VanAlstine (2011). Pre-service elementary education teachers: An international approach to music methods coursework. (Ph. D. Dissertation), University of Minnesota, Retrieved from http://conservancy.umn.edu/bitstream/113638/1/Author_umn_0130E_12052.pdf Available from University of Minnesota Conservancy UMN database.

Veblen, K. K., \& Elliott, D. J. (2000). Integration for or against? General Music Today, 14, 4-8.

Walker, G. (2000). International education: Connecting the national to the global. In M. Hayden \& J. Thompson (Eds.), International schools and international education: Improving teaching, management, and quality (pp. 193-204). Sterling, VA: Stylus Publishing Inc.

Walker, G. (2002). To Educate the Nations: Reflections on an International Education. To Educate the Nations: John Catt Educational Ltd.

Watson, K. (1999). Comparative educational research: The need for reconceptualisation and fresh insights. Compare, 29(3), 233-248. http://dx.doi.org/10.1080/0305792990290304

Wink, J. (2004). Critical pedagogy: Notes from the real world. Boston, MA: Pearson Education, Inc.

\section{$(\mathrm{cc}) \mathrm{EY}$}

This work is licensed under a Creative Commons Attribution 3.0 License. 